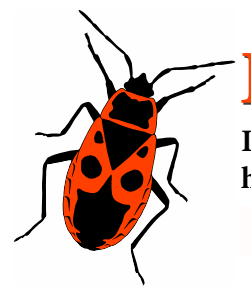

EUROPEAN JOURNAL OF ENTOMOLOGY

ISSN (online): 1802-8829

http://www.eje.cz

Eur. J. Entomol. 113: 122-129, 2016

doi: 10.14411/eje.2016.015

ORIGINAL ARTICLE

\title{
Benthic communities in inland salinized waters with different salinities and nutrient concentrations and the ecology of Chironomus aprilinus (Diptera: Chironomidae) in the Czech Republic
}

\author{
Josef MATĚNA ${ }^{1}$, Iva ŠímOVÁ2, JAKUB BROM ${ }^{2}$ and KATEŘINA NOVOTNÁ ${ }^{2}$ \\ ${ }^{1}$ Institute of Hydrobiology, Biology Centre, Czech Academy of Science, Na Sádkách 7, 37005 České Budějovice, \\ Czech Republic; e-mail: matena@hbu.cas.cz \\ ${ }^{2}$ Faculty of Agriculture, University of South Bohemia, Studentská 13, 37006 České Budějovice, Czech Republic; \\ e-mails: isimova@zf.jcu.cz, jbrom@zf.jcu.cz, wotavova@zf.jcu.cz
}

Key words. Diptera, Chironomidae, Chironomus aprilinus, coal mining, hydric restoration, saline inland waters, fertilization

\begin{abstract}
The macrozoobenthos in saline pools at dumps in a former coal mining area was studied over a period of two years. Due to specific environmental conditions these pools are unique in the Czech Republic. Extremely high values of salinity (up to $11 \%$ ) along with a low concentration of dissolved phosphorus $\left(0.01-0.1 \mathrm{mg}^{. \mathrm{I}^{-1}}\right)$ are typical of some of the water in this area. The pools were grouped into three categories based on their conductivity values and treated using cow dung, municipal wastewater treatment sludge and inorganic NPK (nitrogen-phosphorus-potassium) fertilizer at doses recommended for carp ponds. The application of fertilizer had a positive effect on the density and biomass of all the groups in the macrozoobenthos. The highest and the lowest increases in macrozoobenthos biomass were recorded after the application of NPK and cow dung, respectively. However, the application of fertilizer had no effect on the diversity of macrozoobenthos. Chironomus aprilinus, recorded in the Czech Republic for the first time, inhabited all pools with conductivity ranges of between $5,000-16,000 \mu$ S.cm ${ }^{-1}$. The density of $C$. aprilinus larvae increased with increasing salinity reaching a maximum of about 17,083 ind. $\mathrm{m}^{-2}$ (biomass $-82 \mathrm{~g} \cdot \mathrm{m}^{-2}$ ). Analysis of C. aprilinus phenology revealed a bivoltine pattern with the summer generation of larvae reaching a maximum in June-July and the overwintering generation in October to November.
\end{abstract}

\section{INTRODUCTION}

The majority of aquatic diptera are restricted to freshwater and only a few species tolerate high salinities. Inland saline waters are unique habitats with typical communities of organisms tolerant of adverse and fluctuating environmental conditions. These systems provide a unique opportunity to study the composition of their biological communities and how they respond to changes in their physico-chemical characteristics. The species diversity in the benthic communities in these waters is very low and often dominated by a few tolerant species, which can however occur in high numbers.

Chironomus aprilinus Meigen, 1818 (syn. Chironomus halophilus Kieffer, 1913, Chironomus obscurus Goetghebuer, 1921) is a halophilous species regularly inhabiting coastal biotopes. It occurs in the shallow southern part of the Baltic Sea (Thienemann, 1954; Palmén \& Aho, 1966; Zettler et al., 1996), the Aral Sea (Aladin et al., 2005), coastal marshes in Spain (Fuentes et al., 2005) and flooded brackish river lagoons in England (Rehfisch, 1994) and Ireland (Healy, 1997). C. aprilinus together with C. salinarius (Kieffer) and Microchironomus deribae (Kieffer) are tolerant of a wide range of saline conditions (Parma \& Krebs, 1977). C. aprilinus is also found together with $C$. riparius, $C$. plumosus and $C$. piger along the coast of the Mediterranean in North Africa in sediments in brackish lagoons (Ramdani et al., 2001).

All the above mentioned localities are mesohaline (salinity $3-8 \%$ ) to polyhaline (salinity $18-30 \%$ ) waters located close to marine ecosystems. There are only a few records of $C$. aprilinus in saline inland waters and brackish saltmarshes (5-29\%o) (Thienemann, 1954; Yadav, 2003). C. aprilinus is able to cope with brackish water conditions $<30 \%$ because of its ability to tolerate an increase in the osmotic concentration of its blood (Cheng, 1976).

The aims of this study were: (i) to describe the benthic communities in saline pools at a coal mining dump in western Bohemia, Czech Republic and their response to gradients in salinity and nutrients, with special attention to $C$. aprilinus, a halophilous species, which is here recorded in the Czech Republic for the first time, (ii) to explain the factors affecting its distribution and phenology and (iii) to follow the effect of applying fertilizer on the biotic communi- 


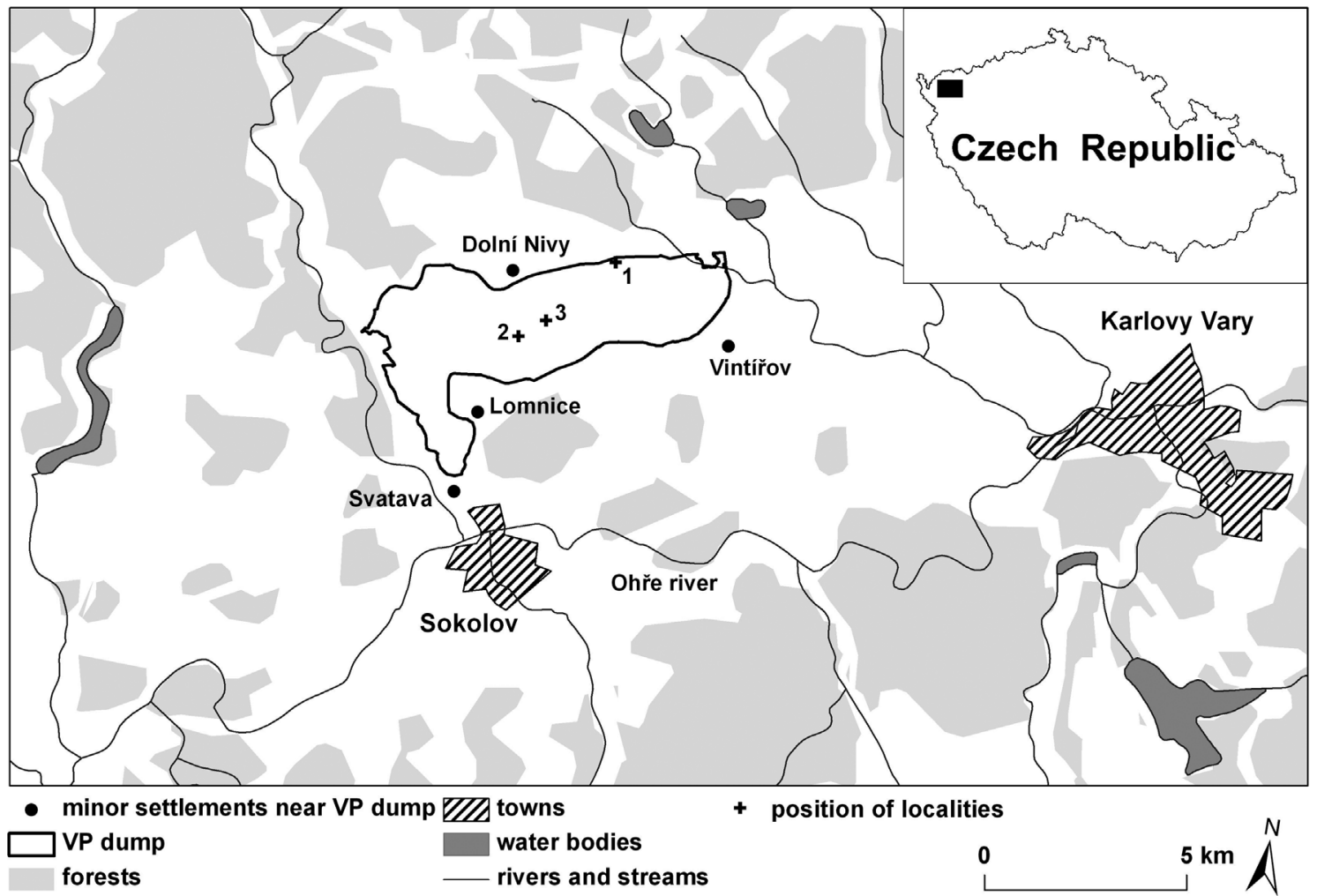

Fig. 1. Map of the Velká Podkrušnohorská (VP) dump with an inset showing its location within the Czech Republic. Numbers 1 to 3 indicate the position of localities studied.

ties and the use of fertilizer for mitigating and accelerating the revitalization of abandoned mining areas.

\section{MATERIAL AND METHODS}

\section{Study area}

This study was carried out in the Sokolov basin, a brown-coal mining region in the west of the Czech Republic. Macrozoobenthos communities were sampled in aquatic habitats created for restoring habitats in the open-cast mine or in areas outside the mining area where overburden from the open-cast mine was dumped (Pecharová et al., 2001).

The Podkrušnohorská dump covers an area of 2,000 ha and is located $3 \mathrm{~km}$ north-west of the city of Sokolov $\left(50^{\circ} 12^{\prime}-50^{\circ} 14^{\prime} \mathrm{N}\right.$, $12^{\circ} 38^{\prime}-12^{\circ} 42^{\prime} \mathrm{E}$ ) (Fig. 1). It is the largest dump in the Czech Republic and consists of overburden from the Jiří, Družba and Lomnice brown coal mines. The overburden consists mostly of montmorillonite kaolinite-illite clays and claystones (Kř́bek et al., 1998). Many pools developed spontaneously at this dump or are newly established as part of the hydric restoration of this former coal-mining region.

Waters in mining areas are often highly acidic due to the leaching by drainage water of compounds present in mine tailings. Thanks to the high neutralization ability of clay, acidification by acid mine drainage (hereafter AMD) water does not play as important a role in the area studied as it does in other coal mining areas throughout the world (Nixdorf at al., 1998; Geller et al., 2000). The $\mathrm{pH}$ values of the water bodies we studied were close to neutral (Table 1). High concentrations of dissolved solids (conductivity up to $16,000 \mu \mathrm{S} . \mathrm{cm}^{-1}$ ), high alkalinity $(8.5-15.5$ mmol. $\left.1^{-1}\right)$ and low concentrations of dissolved phosphorus (0.06$\left.0.7 \mathrm{mg} .1^{-1}\right)$ are typical of water at the Podkrušnohorská dump. Salinity of 3-11\%o corresponds to slightly brackish (mesohaline) water (Healy, 1997; Pitter, 2009). Unlike in seawater, the pre- vailing ions include the bivalent ions of calcium, magnesium and sulphates $(70 \%$ of total dissolved solids) together with carbonates, instead of the monovalent ions of sodium and chloride in sea water, which contains up to $70 \%$ sodium chloride. Other indicators were within the range of surface waters in the Czech Republic, see Table 1.

The pools were grouped into three categories according to their locality, conductivity and presence of littoral and submerged vegetation (Table 1). The conductivity recorded in the pools at the different localities did not overlap. The pools had a surface area of $15-45 \mathrm{~m}^{2}$ at locality $1 ; 20 \mathrm{~m}^{2}$ at locality 2 and $250-1000 \mathrm{~m}^{2}$ at locality 3 . The depth was about $30 \mathrm{~cm}$ at localities 1 and 2 and 50 $\mathrm{cm}$ at locality 3 .

Application of fertilizers was used to determine the possibility of accelerating the biotic recovery of the pools studied. Cow dung, municipal wastewater treatment sludge or inorganic NPK fertilizer (commercial CERERIT, $\mathrm{N}-15 \%, \mathrm{P}_{2} \mathrm{O}_{5}-15 \%, \mathrm{~K}_{2} \mathrm{O}-$ $15 \%$ ) was added to particular pools in early August 2001. NPK fertilizer was also added to pools at locality 2 in early September as shown in Table 1. The dose of fertilizers was chosen so that the final concentration of TP was $0.8 \mathrm{mg} . \mathrm{l}^{-1}$ in the pools to which fertilizers were added. The wastewater treatment sludge and cow dung were applied at the maximum dose of $5 \mathrm{t} \mathrm{ha}^{-1}$, which is the dose applied to semi-intensively managed carp ponds.

\section{Environmental and biological sampling}

Water samples, $100 \mathrm{ml}$ each, were collected monthly from each pool. The $\mathrm{pH}$, conductivity and oxygen concentration were measured in situ using a Multiline P4 device (WTE, Germany). Salinity (mg. $\mathrm{l}^{-1}$ ) was calculated from the conductivity measurements using conversion factor 8 as per Pitter (2009). In the laboratory, $\mathrm{NH}_{4}^{+}, \mathrm{NO}_{3}^{-}, \mathrm{NO}_{2}^{-}, \mathrm{PO}_{4}{ }^{3-}, \mathrm{SO}_{4}{ }^{2-}, \mathrm{Cl}^{-}$, total $\mathrm{N}$ and total $\mathrm{P}$ concentrations were measured after filtration $(\mathrm{GF} / \mathrm{C}$ filters), using a flow injection analyses method and a Tecator FIA 5042 Star instrument 
Table 1. Characteristics and chemical parameters recorded at the localities studied and carp ponds in the Czech Republic (highest values are in bold).

\begin{tabular}{|c|c|c|c|c|c|}
\hline & Unit & Locality 1 & Locality 2 & Locality 3 & $\begin{array}{c}\text { Average values of carp } \\
\text { ponds in the Czech Republic } \\
\text { (Hartman et al., 1998) }\end{array}$ \\
\hline Status & & artificial & artificial & natural & \\
\hline Number of pools & & 12 & 11 & 4 & \\
\hline Age of pools (years) & & 2 & 1 & 10 & \\
\hline Vegetation & & $\begin{array}{l}\text { Chara sp. } \\
\text { Typha angustifolia } \\
\text { Potamogeton sp. }\end{array}$ & $\begin{array}{l}\text { no vegetation } \\
\text { artificial substrate } \\
\text { in water column }\end{array}$ & $\begin{array}{l}\text { Chara sp. } \\
\text { Typha angustifolia } \\
\text { Potamogeton sp. }\end{array}$ & \\
\hline $\begin{array}{l}\text { Treatment/ } \\
\text { number of pools }\end{array}$ & & $\begin{array}{c}\text { NPK/4 } \\
\text { Sludge/4 } \\
\text { Control/4 }\end{array}$ & $\begin{array}{c}\text { NPK/2 } \\
\text { Sludge/2 } \\
\text { Cow dung/2 } \\
\text { Conrol/5 }\end{array}$ & $\begin{array}{c}\text { NPK/3 } \\
\text { Control/1 }\end{array}$ & \\
\hline $\begin{array}{l}\mathrm{pH} \\
\text { Alkalinity } \mathrm{ANC}_{45}\end{array}$ & mmol. $\left.\right|^{-1}$ & $\begin{array}{l}1.4-0.1 \\
8.5-12.6\end{array}$ & $\begin{array}{l}7.8-8.4 \\
6.4-8.8\end{array}$ & $\begin{array}{c}8.2-8.3 \\
11.2-15.8\end{array}$ & $\begin{array}{l}5.5-9.5 \\
0.25-6\end{array}$ \\
\hline Conductivity & $\mu \mathrm{S} . \mathrm{cm}^{-1}$ & $4000-6400$ & $9000-11500$ & $12300-16300$ & $100-600$ \\
\hline $\mathrm{N}-\mathrm{NH}_{4}$ & $\mathrm{mg} . \mathrm{I}^{-1}$ & $0.06-0.79$ & $0.18-0.99$ & $0.3-2.3$ & $0.01-1.2$ \\
\hline $\mathrm{N}-\mathrm{NO}_{3}$ & $\mathrm{mg} . \mathrm{I}^{-1}$ & $0.14-0.63$ & $0.44-1.15$ & $0.08-0.25$ & $0.05-3$ \\
\hline $\mathrm{TP}^{3}$ & $\mathrm{mg} . \mathrm{I}^{-1}$ & $0.06-0.15$ & $0.08-0.15$ & $0.08-0.77$ & $0.025-1.4$ \\
\hline $\mathrm{Na}^{+}$ & $\mathrm{mg} . \mathrm{l}^{-1}$ & $130-670$ & $1700-2520$ & $2200-2900$ & $4-85$ \\
\hline $\mathrm{K}^{+}$ & $\mathrm{mg} \cdot \mathrm{l}^{-1}$ & $20-30$ & $20-30$ & $40-50$ & $1-35$ \\
\hline $\mathrm{Ca}^{2+}$ & $\mathrm{mg} . \mathrm{I}^{-1}$ & $30-130$ & $90-120$ & $160-250$ & $10-100$ \\
\hline $\mathrm{Mg}^{2+}$ & $\mathrm{mg} \cdot \mathrm{l}^{-1}$ & $80-240$ & $330-400$ & $740-910$ & $1-60$ \\
\hline $\mathrm{Cl}^{-}$ & $\mathrm{mg} . \mathrm{I}^{-1}$ & $1.8-2.9$ & $0.7-1.2$ & $0.5-0.8$ & $5-90$ \\
\hline $\mathrm{SO}_{4}^{2-}$ & $\mathrm{mg} \cdot \mathrm{l}^{-1}$ & $1700-4100$ & $5200-9800$ & $13800-15800$ & $30-250$ \\
\hline $\mathrm{Fe}^{4}$ & $\mathrm{mg} \cdot \mathrm{I}^{-1}$ & $0.2-0.5$ & $0.1-0.7$ & $0.2-0.7$ & $0.05-0.6$ \\
\hline
\end{tabular}

(Parsons et al., 1984). The concentrations of $\mathrm{Ca}, \mathrm{Mg}, \mathrm{K}, \mathrm{Na}$ and Fe cations were determined using the AAS method and a Varian SpectrAA-640 instrument (Varian Inc., http://www.varianinc. com). Alkalinity was measured by potentiometric titration with $0.1 \mathrm{M} \mathrm{HCl}$.

Samples of macrozoobenthos were collected monthly from July until November 2001 (except August) and from February till October 2002 (except August). Each sample consisted of 10 subsamples pooled together. Individual quantitative subsamples were collected using a plastic cylindrical corer (working area 96 $\left.\mathrm{cm}^{2}\right)$. Samples were washed through a sieve (1.0 mm mesh size) and fixed using $6 \%$ formaldehyde. The remaining benthic invertebrates on the sieve were sorted by hand in the laboratory. Biomass was assessed as formalin wet weight. In each sample, the biomass and species composition of the macrozoobenthos were determined. The larvae of $C$. aprilinus were identified morphologically (Webb \& Scholl, 1985) and cytotaxonomically using the polythene chromosomes in the salivary glands (Keyl \& Keyl, 1959; Keyl, 1962) of a sample of unpreserved material. Size data for all the $C$. aprilinus larvae were assessed in terms of body length (measured from the anterior margin of the labrum to the end of the abdomen) and larval instar based on head width (at the widest point of head capsula) (Saether, 1980).

\section{Statistical analyses}

Direct gradient redundancy analysis (RDA) in Canoco for Windows 4.5 software (Ter Braak \& Šmilauer, 1998) was used to evaluate the association of all the environmental variables recorded (vegetation cover, alkalinity, type of fertilization, chlorophyll a, conductivity, $\mathrm{Cl}^{-}, \mathrm{NH}_{4}^{+}, \mathrm{PO}_{4}^{3-}$ and seasonality as individual month of observations) with the macrozoobenthos community [total abundance of zoobenthos, abundance and biomass of $C$. aprilinus, the percentage of $C$. aprilinus, Shannon-Wiener index $H^{\prime}=-\Sigma i$ pi lnp $i(H-$ calculated using natural logarithms of relative densities of particular taxa)] and equitability index $\mathrm{E}$ $=H^{\prime} / \operatorname{lnS}$, where $\mathrm{S}$ is the number of taxa in a sample. Statistical significance of each analysis was tested using the Monte Carlo permutation test with 499 permutations as a time series and pools set as covariates. The analysis was visualized using CanoDraw software (Ter Braak \& Šmilauer, 2002). Level of significance was set to $\alpha \leq 0.05$ in all statistical comparisons.

For analysis of differences in species abundance/numbers between localities two-way ANOVA and for analyses of statistical comparison of average $C$. aprilinus abundance in different treatments one-way ANOVA in STATISTICA software version 12.0 (Statsoft Inc., 2008) was used.

The association between presence/absence of $C$. aprilinus and environmental factors (vegetation cover, age of reservoirs, water electric conductivity) and their interactions was tested using a generalized linear model with a binomial error distribution and a logit link.

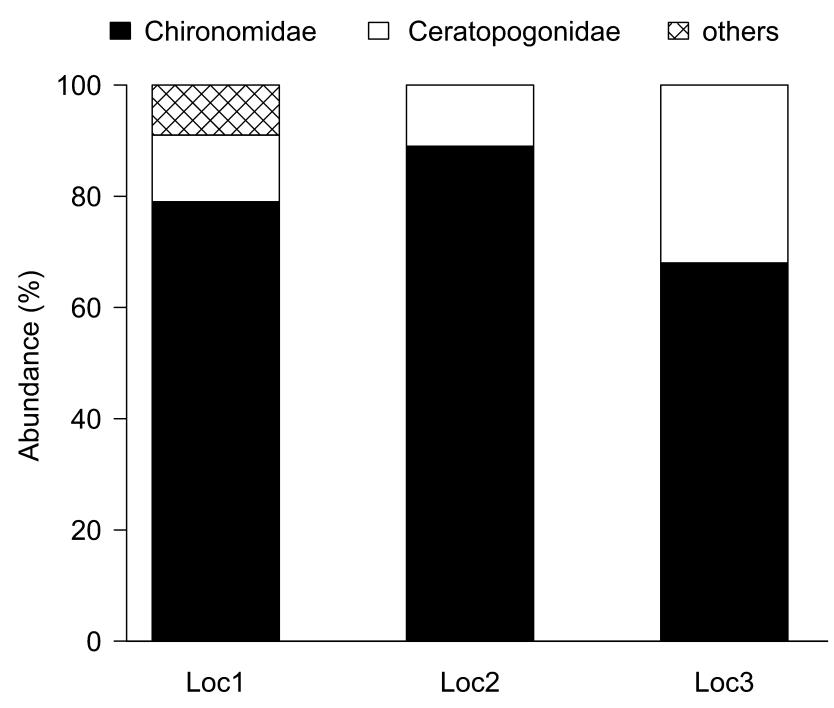

Fig. 2. Percentage composition of macrozoobenthos at localities $1-3$. Mean percentage abundance for all the pools at each locality is presented. 
C. aprilinus $\square$ Procladius $\mathbf{m}$ Tanypus $\square$ Tanytarsus $\square$ others

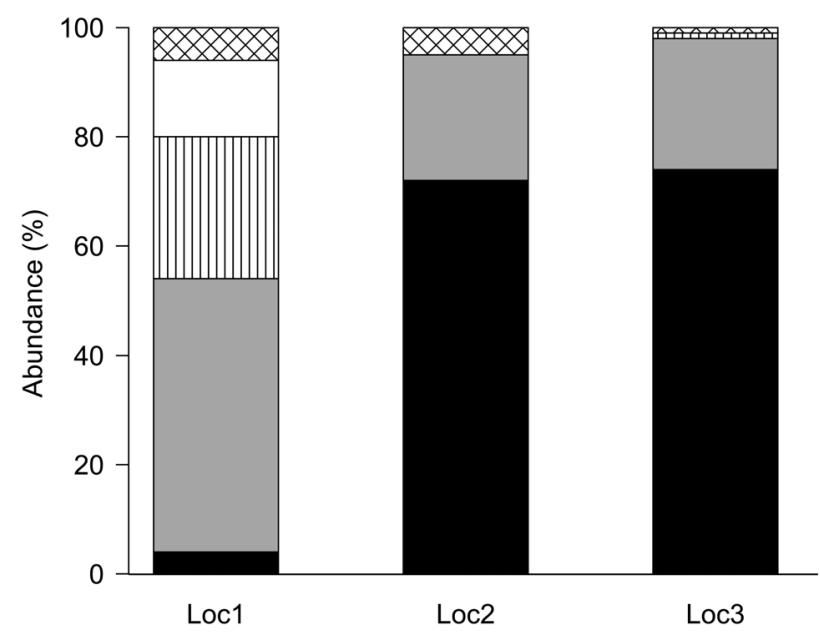

Fig. 3. Percentage composition of chironomid larvae at localities $1-3$. Mean percentage abundance for all pools at each locality is presented.

\section{RESULTS}

\section{Occurrence of macrozoobenthos at the different localities}

Chironomid larvae dominated the benthic communities' at all three localities, making up $70-90 \%$ of the total macrozoobenthos abundance (Fig. 2). At localities 2 and 3, the percentage made up of Chironomus larvae exceeded $70 \%$ (Fig. 3). Larvae of C. aprilinus made up on average $72 \%$ of the total chironomid abundance at locality 2 (conductivity $9,000-11,500 \mu \mathrm{S} . \mathrm{cm}^{-1}$ ) and $74 \%$ at locality 3 (conductivity $\left.>12,000 \mu \mathrm{S} . \mathrm{cm}^{-1}\right)$.

The abundance of particular groups of macrozoobenthos (Chironomidae, Ceratopogonidae and others) differed significantly between localities (Two-way ANOVA, $\mathrm{F}_{(4,849)}$ $=4.824, \mathrm{p}=0.00075)$. The highest species richness was recorded at locality 1 where the other categories (Ephemeroptera, Odonata, Coleoptera, Diptera: Stratiomyidae) made up about $10 \%$ of total numbers. At the other two localities they made up less than $1 \%$ of the total numbers (Fig. 2). Similarly the number of chironomid taxa differed significantly between localities (Two-way ANOVA, $\mathrm{F}_{(8,1415)}$ $=18.890, \mathrm{p}<0.00001)$. At localities 2 and 3 C. aprilinus made up about $70 \%$ of all chironomids and at locality 1 only 5\%. On the other hand, larvae of Procladius made up $50 \%$ of all chironomids at locality 1 and only $23 \%$ at localities 2 and 3 .
The highest species diversity was recorded in pools with the lowest conductivity at locality $1\left(4,000-6,400 \mu \mathrm{S} . \mathrm{cm}^{-1}\right)$. Larvae of Procladius, Tanypus and Tanytarsus made up more than $90 \%$ whereas Chironomus larvae made up only $4 \%$ of all chironomid larvae and were found in only 5 of the 12 pools studied (Fig. 3). An exceptionally high density of 10,417 ind. $\mathrm{m}^{-2}$ (biomass $21 \mathrm{~g} . \mathrm{m}^{-2}$ ) of C. aprilinus was recorded in June 2002 at one pool with a conductivity of $5,700 \mu \mathrm{S} . \mathrm{cm}^{-1}$. The numbers were lower by an order of magnitude in the other pools at locality 1 . The diversity index $\mathrm{H}^{\prime}$ was significantly positively correlated with the presence of aquatic vegetation (Fig. 6).

\section{Factors affecting abundance and biomass}

The application of fertilizers had a positive effect on zoobenthos at all three localities. The highest average abundance of $C$. aprilinus was recorded in pools fertilized with NPK at all three localities in 2002 (Fig. 4). The difference between the densities of $C$. aprilinus recorded in pools fertilized with NPK and those treated with sludge and the control pools that were not treated with fertilizers was significant (One-way ANOVA, $\mathrm{F}_{(3,272)}=11.22 ; \mathrm{p}<$ 0.001) (Fig. 5).

The highest average densities of $C$. aprilinus were recorded in pools treated with inorganic NPK in 2002 (Fig. 4). The only exception were the pools at locality 2 in the first two months after the application of wastewater treatment sludge (October and November 2001). Maximum densities were recorded in some pools at locality 2 in November 2001 (7,083 ind. $\mathrm{m}^{-2}, 38$ g. $\left.\mathrm{m}^{-2}\right)$ and June, July 2002 $\left(6,875\right.$ ind. $\mathrm{m}^{-2}, 35.8$ g. $\left.\mathrm{m}^{-2}\right),\left(7,188\right.$ ind. $\mathrm{m}^{-2}\left(62.4\right.$ g.m $\left.\mathrm{m}^{-2}\right)$, respectively. At locality 3, C. aprilinus reached peaks in abundance in September 2001 (10,208 ind. $\mathrm{m}^{-2}, 23.7$ g.m $\left.{ }^{-2}\right)$ and June 2002 (17,083 ind. $\mathrm{m}^{-2}, 66.4$ g.m $\left.{ }^{-2}\right)$. All these high values were recorded in pools fertilized with NPK. In control pools without fertilization at this locality, C. aprilinus made up between $10-20 \%$ of total abundance of macrozoobenthos and $80 \%$ of the larvae belonged to the family Ceratopogonidae.

Factors affecting the abundance and biomass of $C$. aprilinus are presented in Fig. 6. The closer the explanatory arrows and explained variables are the closer they are positively correlated. Opposite direction of arrows indicates a negative correlation. The variability in the abundance and biomass of $C$. aprilinus and total diversity $\left(\mathrm{H}^{\prime}\right)$ is best explained by the time of year - June ( $4 \%$ of total variance explained by all factors, $\mathrm{F}=11.99, \mathrm{p}=0.002)$. After including this variable in the model, most of the residual variance

Table 2. GLM analysis of the relationship presence / absence of Ch. aprilinus and the age of the pools, conductivity and presence of vegetation ${ }^{* * *} p<0.001,{ }^{* *} p<0.01,{ }^{*} p<0.1$, n.s. $\left.-p>0.5\right)$.

\begin{tabular}{|c|c|c|c|c|c|}
\hline & Df & Dev.Resid. & Df Resid. & DevPr & p level \\
\hline vegetation & 1 & 15.586 & 284 & 380.54 & $* * *$ \\
\hline age & 1 & 44.295 & 283 & 336.25 & $* * *$ \\
\hline conductivity & 1 & 1.541 & 282 & 334.71 & n.s. \\
\hline vegetation $\times$ age & 1 & 5.987 & 281 & 328.72 & * \\
\hline vegetation $\times$ conductivity & 1 & 4.034 & 280 & 324.69 & * \\
\hline age $\times$ conductivity & 1 & 0.033 & 279 & 324.66 & n.s. \\
\hline vegetation $\times$ age $\times$ conductivity & 1 & 9.825 & 279 & 314.83 & $\star *$ \\
\hline
\end{tabular}




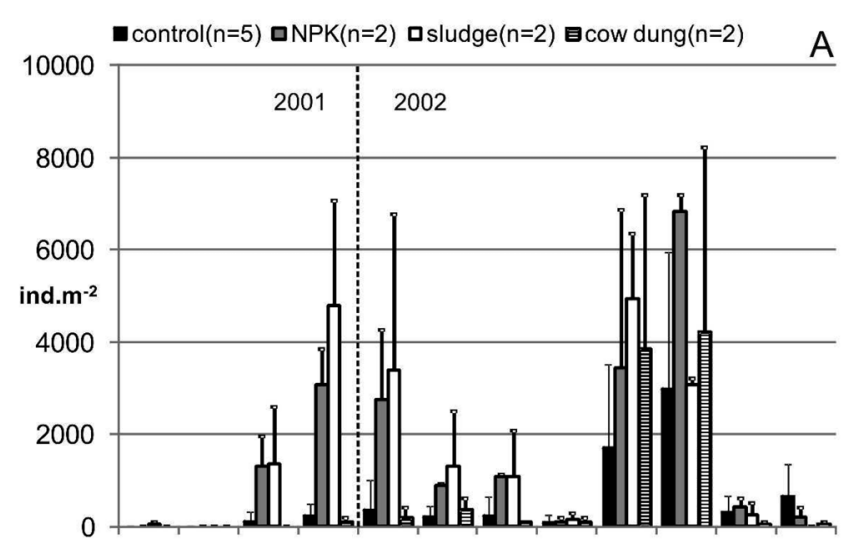

Jul Sep Oct Nov Feb Mar Apr May Jun Jul Sep Oct

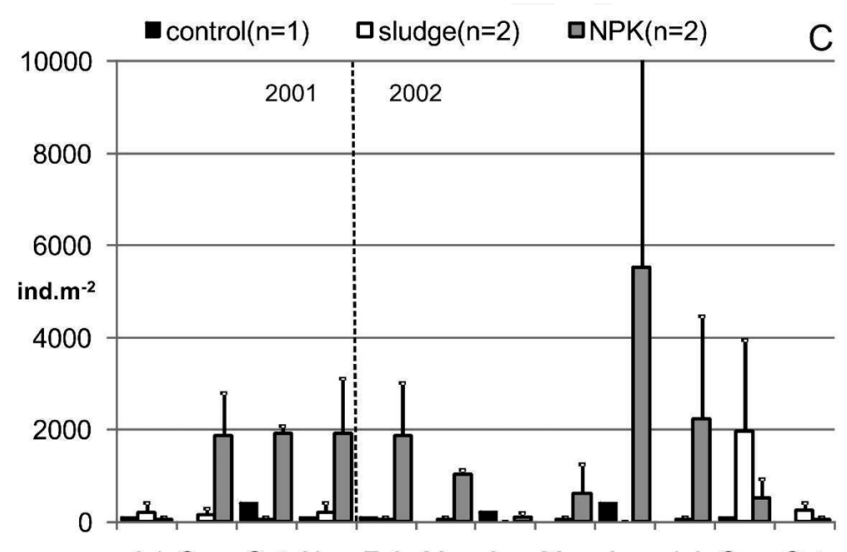

Jul Sep Oct Nov Feb Mar Apr May Jun Jul Sep Oct

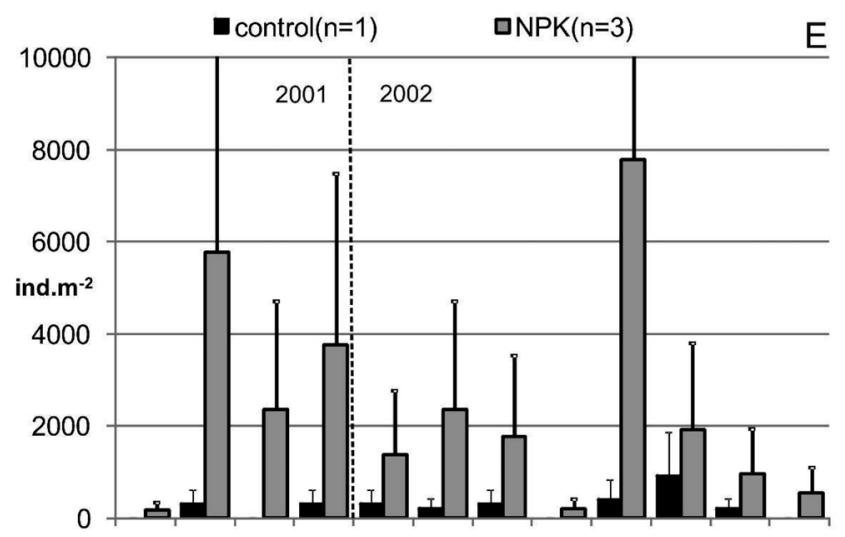

Jul Sep Oct Nov Feb Mar Apr May Jun Jul Sep Oct
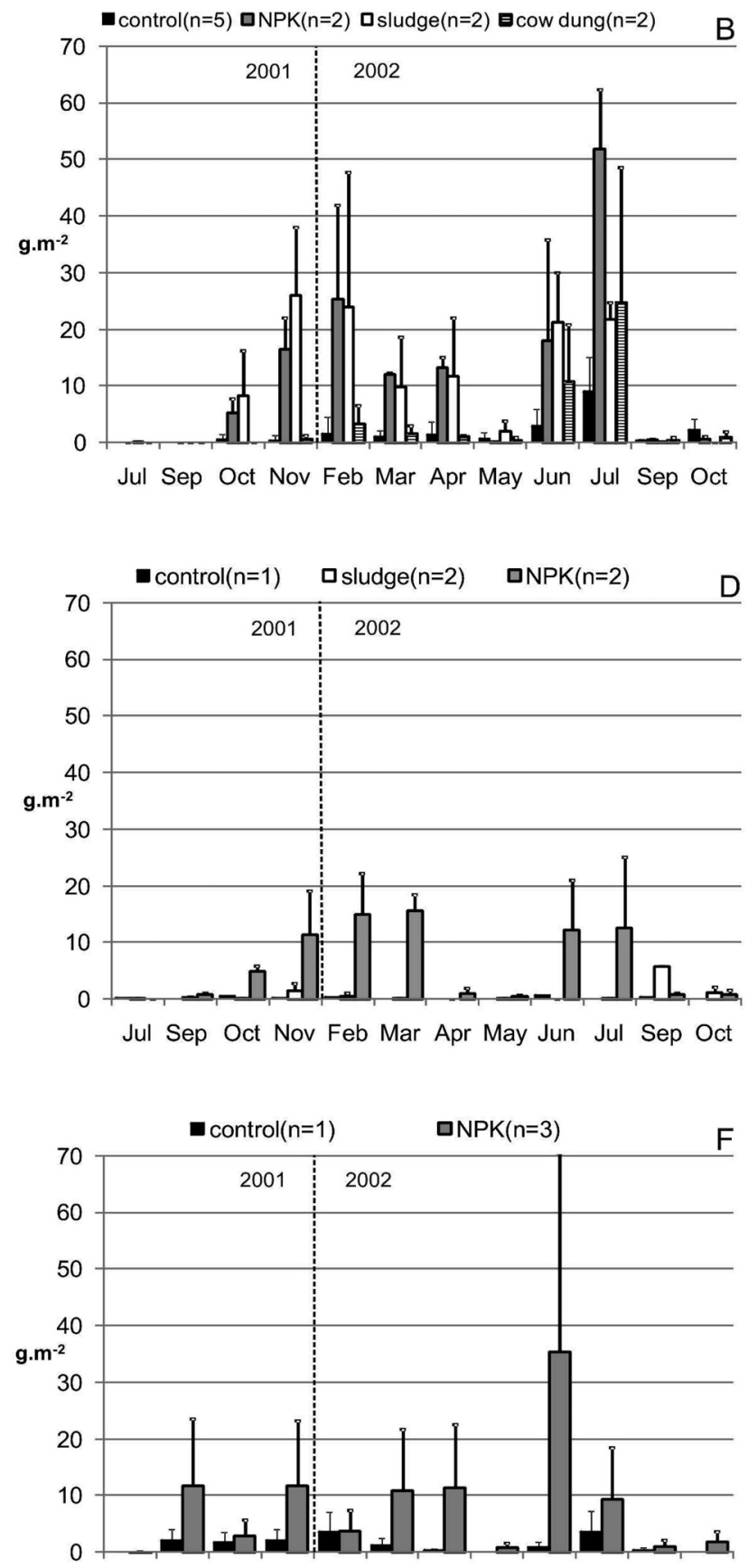

Jul Sep Oct Nov Feb Mar Apr May Jun Jul Sep Oct

Fig. 4. Effect of fertilizers on the abundance (left column) and biomass (right column) of C. aprilinus; locality 1 (A-B), locality 2 (C-D), locality $3(\mathrm{E}-\mathrm{F}) ; \mathrm{n}=$ number of pools with $C$. aprilinus.

is explained by the presence of vegetation $(3 \%, \mathrm{~F}=9.53$, $\mathrm{p}=0.002)$, November $(2 \%, \mathrm{~F}=7.21, \mathrm{p}=0.002)$, chlorophyll a $(2 \%, \mathrm{~F}=8.88, \mathrm{p}=0.008)$, application of NPK $(2 \%, F=7.02, p=0.002)$ and one percent of the variability can be explained by the following factors: July, alkalinity, February, March, control. Further variables proved to be insignificant.

The results of the GLM (Table 2) revealed a negative correlation between the occurrence of $C$. aprilinus and the presence of vegetation in pools but, this relationship is probably indirect as the presence of vegetation is primarily correlated with the salinity of habitats.

\section{Seasonal dynamics}

Average densities and biomass of $C$. aprilinus larvae changed seasonally. Maxima were recorded during autumn (September to November) and summer (June to July) (Figs 4 and 6). The summer maximum biomass was higher than that recorded in autumn. Length analysis (Fig. 7) and changes in abundance and biomass (Fig. 4) indicated a bivoltine cycle in the population. Larvae of the $3^{\text {rd }}$ instar (length 3-9 mm) dominated in September to October. They grew during the winter and the highest occurrence of $4^{\text {th }}$ instar larvae was recorded in February and March. The emer- 


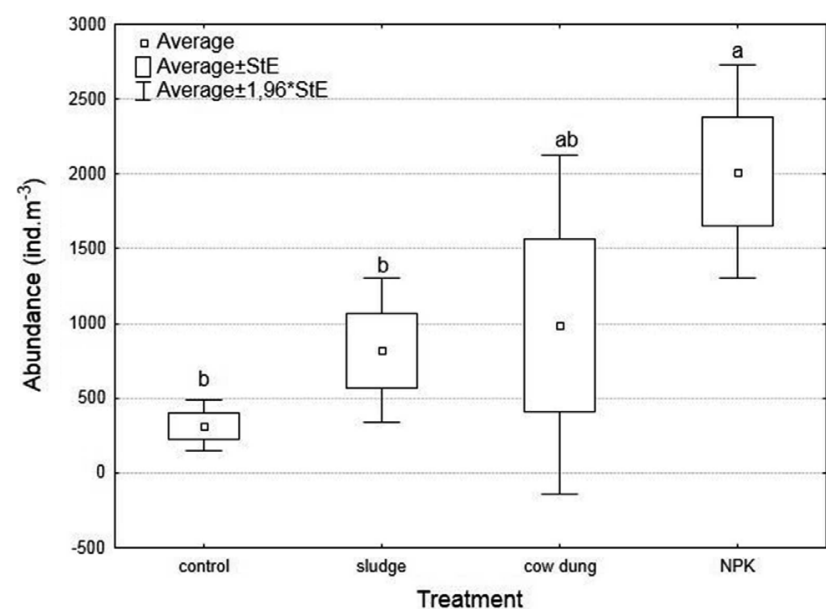

Fig. 5. Statistical comparison of average abundance of $C$. aprilinus in the different treatments. One way ANOVA, different letters above boxes indicate significant differences $(p<0.001)$.

gence of the overwintering generation started in March/ April at locality 1, depending on weather. Mass emergence took place in May at localities 2 and 3. After that low numbers of C. aprilinus larvae were recorded at all localities in May (Fig. 4). Larvae of the $1^{\text {st }}$ and $2^{\text {nd }}$ instars were regularly found in zooplankton samples taken at all three localities in March to July. The emergence of the summer generation was more protracted and occurred during August and

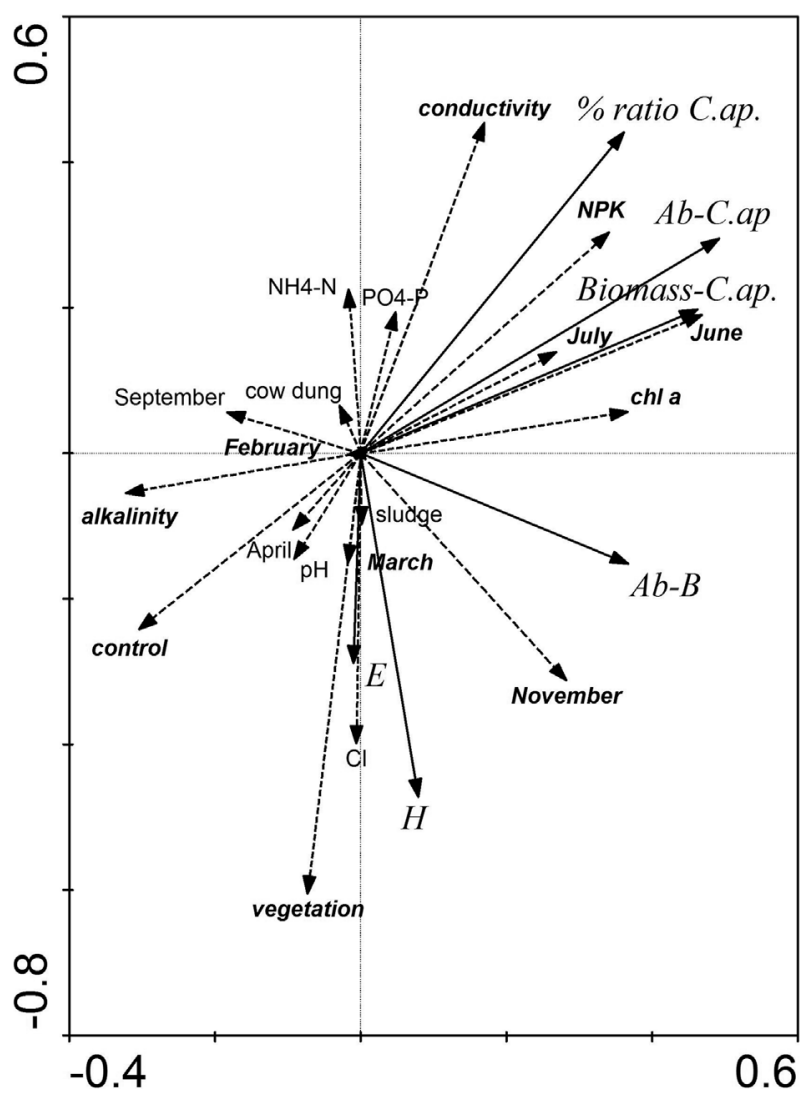

Fig. 6. Results of RDA analysis of selected variables. First axes explain $16.5 \%$ of variability, second $4.1 \%$. (Marks in bold and italics are statistically significant.) Ab-C.ap - abundance of $C$. aprilinus, $\mathrm{Ab}-\mathrm{B}$ - abundance of total benthos, $\mathrm{H}$ - Shannon-Wiener index $\mathrm{E}-$ equitability index.
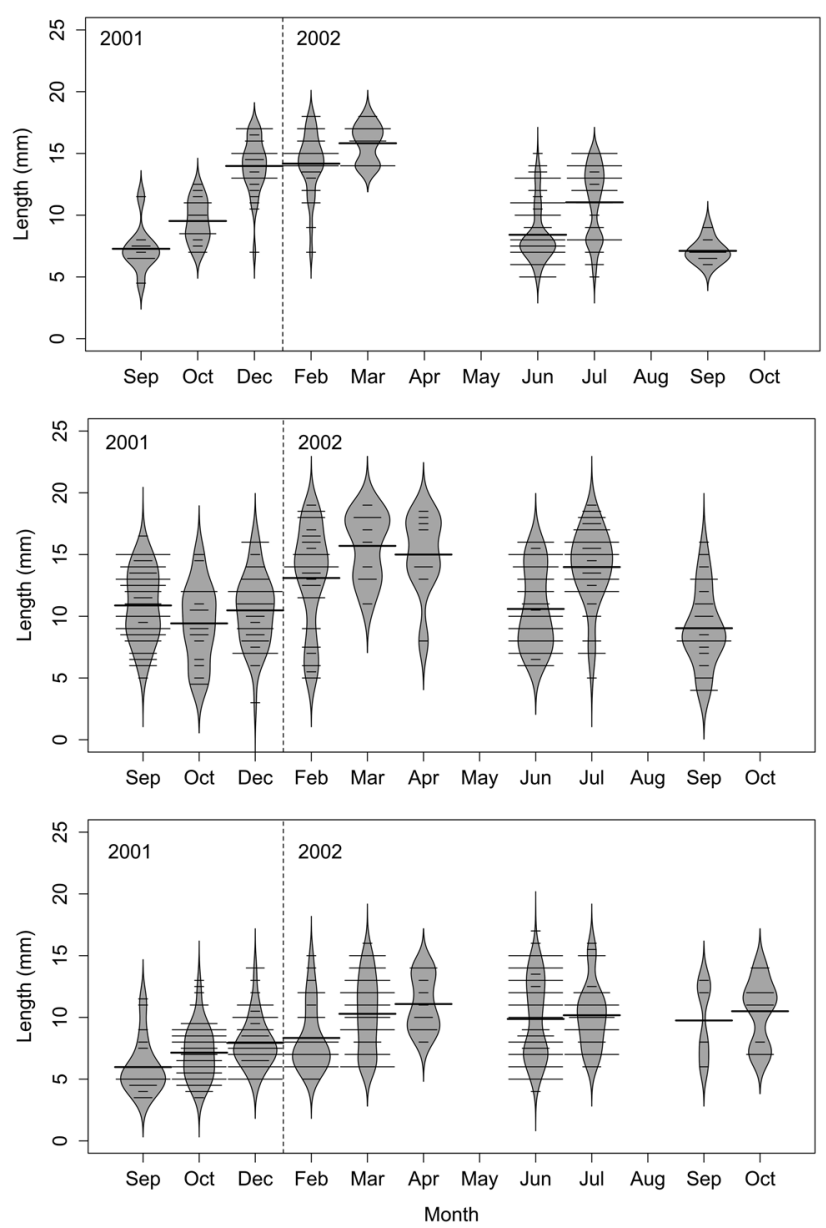

Fig. 7. Length frequency distributions of $C$. aprilinus larvae over time. Upper panel - locality 1 , middle - locality 2 , bottom panel - locality 3. Bold horizontal bars indicate the average length for a given month, narrow bars indicate numbers of larvae in a given length class. Each bean plot shows the length frequency recorded in each month and is smoothed using a Gaussian kernel.

Sepember. In September the larvae of the 4th instar disappear from the benthos and the population was dominated by $3^{\text {rd }}$ instar larvae of the overwintering generation (Fig. 7). The two generations were well separated at localities 1 and 2 , whereas they overlapped at locality 3 .

\section{DISCUSSION}

Saline pools at the dumps in a former coal mining area are unique habitats with a fauna found nowhere else in the Czech Republic. The inland saline pools differed from coastal waters in their water chemistry. The salinity was due mainly to sulphates and corresponds to mesohaline conditions. Chironomus aprilinus was recorded at these localities in the Czech Republic for the first time. Besides $C$. aprilinus, other halophilous organisms were also recorded, e.g., the rotifer Hexarthra fennica (Levander) and larvae of Ephydra cf. riparia (Diptera: Ephydridae).

The macrozoobenthos was dominated by chironomids in both recent and old pools, and the occurrence of C. aprilinus was positively correlated with salinity. Strenzke (1960) reports females only depositing eggs in brackish water with a chloride content of 4000-13700 $\mathrm{mg} \mathrm{l}^{-1}$ under experimental conditions. The same author found this species in natu- 
ral conditions in Germany at salinities of 1,200-16,100 mg $1^{-1}$. Tourenq (1975) reports incidental occurrence in fresh water but gave $1,500-6,000 \mathrm{mg} \mathrm{l}^{-1}$ as the normal range. He found, however, larvae of this species in places where the chloride content was as high as $15,000-22,000 \mathrm{mg} \mathrm{l}^{-1}$. Steenbergen (1993) cites a mean of 5,800 $\mathrm{mg} \mathrm{l}^{-1}$ and rarely recorded larvae below $1,000 \mathrm{mg} \mathrm{l}^{-1}$. Vallenduuk in Eggermont et al. (2008) reports conductivity limits of 3,000$5,000 \mu \mathrm{S} . \mathrm{cm}^{-2}$ for the occurrence of $C$. aprilinus.

These results are in good agreement with the salinity range recorded at the pools studied $\left(3,200-13,040 \mathrm{mg} \mathrm{l}^{-1}\right)$. However, at the locality with the lowest salinity $(3,200$ $6,400 \mathrm{mg} \mathrm{l}^{-1}$ ) not all pools were inhabited by $C$. aprilinus.

The biomass of benthic and planktonic communities depends on the primary production of autotrophic organisms, which is limited mainly by the availability of phosphorus and nitrogen in the water column. The availability of nutrients, along with high conductivity, is the limiting factor of productivity in water biotopes. As a result, poor development of phytoplankton and littoral macrophytes was recorded at the different localities studied. The application of fertilizers is the fastest method, but not the most longlasting, to support primary producers in these ecosystems and subsequent development of the macrozoobenthos. The genus Chironomus is tolerant of eutrophic conditions (Marquez et al., 1999). This was confirmed in our study. Larvae of the sub-family Chironominae showed a significant increase in abundance in response to organic enrichment. The larvae of Chironomus dominated in fertlized pools at all salinities.

Chironomid larvae play a pivotal role as potential drivers of nutrient dynamics. The role of chironomids is not only as an important source of food for benthic fish, but also as a major contributor to the phosphorus flux from sediments in ponds with a residual organic load (Biswas et al., 2009), especially in pools without fish.

The analysis of the phenology of $C$. aprilinus revealed a bivoltine cycle with possibly a partial third generation. These findings are in agreement with the results of other studies. Palmén \& Aho (1966) report two generations of C. aprilinus in southern Finland, but only one in cold environments and possibly a partial third generation in warm years. In the delta region of the Netherlands, Krebs (1982) recorded two generations a year (sometimes three), emerging from the end of March until early November. Larvae overwinter in the third or fourth instar. Spring and autumn emergence of Chironomidae is typical in temperate wetlands (Armitage at al., 1995; Moeller-Pillot, 2009). In warmer climatic conditions there are likely to be more generations per year and the emergence of the overwintering generation can take place earlier. Fuentes et al. (2005) found high densities of $3^{\text {rd }}$ and $4^{\text {th }}$ instar larvae in May, which may correspond to the first summer generation. Similarly, Rajabipour et al. (2011) show that May, June and July are the best months for collecting egg clutches of $C$. aprilinus. At our localities we recorded larval minima in May. Due to the sampling method used, the small larvae of the first two instars passed through the sieve. Moreover, it is difficult to sample the first two instars as they only take a few days to complete their development (Matěna, 1989).

The total absence of another halophilous to halobiont species $C$. salinarius Kieffer is interesting. This species is regularly reported as syntopic with $C$. aprilinus along seashores worldwide (Parma \& Krebs, 1977; Drake \& Arias, 1995; Kondo, 1998). According to Cartier et al. (2006) $C$. salinarius can tolerate variation in salinity with very few individuals surviving in environments with a salinity level over $35 \mathrm{~g} \mathrm{l}^{-1}$, high survival at low salinities $\left(0\right.$ and $\left.5 \mathrm{~g} \mathrm{l}^{-1}\right)$ and moderately high salinities $\left(20,25\right.$ and $\left.30 \mathrm{~g} \mathrm{l}^{-1}\right)$ and poor survival at intermediate levels of salinity (10 and $15 \mathrm{~g}$ $1^{-1}$ ). So the salinities of the pools investigated were within the range tolerated by this species.

We can suggest two reasons for the absence of $C$. salinarius in the pools examined in this study. The species is either bound to habitats close to the seashore where the salinity is determined by a high content of chlorides and is unable to cope with high concentrations of sulphates or only $C$. aprilinus is capable of dispersing from coastal areas because it can tolerate freshwater habitats and so use such places as stepping stones to find more suitable habitats. These hypotheses require further study.

ACKNOWLEDGEMENTS. This study was carried out at the Laboratory of Applied Ecology, Faculty of Agriculture University of South Bohemia in České Budějovice supported by projects NAZV QH82106 and MSM 122200003/1. The first author received institutional support from RVO. 60077344.

\section{REFERENCES}

Aladin N., Crétaux J.-F., Plotnikov I.S., Kouraev A.V., Smurov A.O., Cazenave A., Egorov A.N. \& Papa F. 2005: Modern hydro-biological state of the Small Aral sea. - Environmetrics 16: 375-392.

Armitrage P., Cranston P.S. \& Pinder L.C.V. 1995: The Chironomidae: The Biology and Ecology of non-Biting Midges. Chapman and Hall, London, 572 pp.

Biswas J.K., Rana S., Bhakta J.N. \& Jana B.B. 2009: Bioturbation potential of chironomid larvae for the sediment-water phosphorus exchange in simulated pond systems of varied nutrient enrichment. — Ecol. Eng. 35: 1444-1453.

Cartier V., Claret C., Garnier E. \& Franquet D. 2006: How salinity affects life cycle of a brackish water species, Chironomus salinarius Kieffer (Diptera: Chironomidae). - J. Exp. Mar. Biol. Ecol. 405: 93-98.

CHeng L. 1976: Marine Insects. North-Holland Publishing Company, Amsterdam, $581 \mathrm{pp}$.

DraKe P. \& ARIAS A.M. 1995: Distribution and production of Chironomus salinarius (Diptera: Chironomidae) in a shallow coastal lagoon in the Bay of Cádiz. — Hydrobiologia 299: 195-206.

Eggermont H., Heiri O. \& Verschuren D. 2006: Subfossil Chironomidae (Insecta: Diptera) as quantitative idicators for past salinity variation in African lakes. - Quat. Sci. Rev. 25: 19661994.

Eggermont H., Verschuren D., Fagot M., Rumes B., Bocxlaer B.V. \& Kröpelin S. 2008: Aquatic community response in a groundwater-fed desert lake to Holocene desiccation of the Sahara. - Quat. Sci. Rev. 27: 2411-2425.

Fuentes C., Green A.J., Orr J. \& Ólafsson J.S. 2005: Seasonal variation in species composition and larval size of the benthic 
chironomid communities in brackish wetlands in southern Alicante. - Wetlands 25: 289-296.

Geller W., Friese K., Herzsprung P., Kringel R., Schimmele M., Schmultze M., Wendt-Potthoff K. \& Wölf S. 2000: Geogene Versauerung von Tagebaurestgewëssern. In Gauderian R. \& Gunkel G. (eds): Handbuch der Umweltveränderungen und Ökotoxikologie. Springer, Berlin, Heidelberg, pp. 352-380.

Hartman P., PřIKRYl I. \& Štědroňský E. 1998: Hydrobiologie. Informatorium, Prague, 335 pp. [in Czech].

HeALY B. 1997: Long-term changes in a brackish lagoon, Lady's Island Lake, South-east Irland. - Biol. Envir. Proc. R. Ir. Acad. (B1) 97: 33-51.

Keyl H.G. 1962: Chromosomenevolution bei Chironomus II. Chromosomenumbauten und phylogenetische Beziehungen der Arten. - Chromosoma 13: 464-514.

Keyl H.G. \& Keyl I. 1959: Die cytologische Diagnostik der Chironomiden. I. Bestimmungstabelle für die Gattung Chironomus auf Grund der Speicheldüsenchromosomen. - Arch. Hydrobiol. 56: 43-57.

Kondo S. 1998: Seasonal abundances of two halophilous chironomids (Diptera: Chironomidae) in a brackish pond of Nagoya City, Japan. - J. Kans. Entomol. Soc. 71: 469-473.

KreBs B.P.M. 1982: Chironomid communities in brackish inland waters. - Chironomus 2: 19-23.

Kříbek B., Strnad M., Boháček Z., SÝkorová I., Čejka J. \& SoBALíK Z. 1998: Geochemistry of Miocene lacustrine sediments from the Sokolov Coal Basin (Czech Republic). - Int. J. Coal Geol. 37: 207-233

Marquez M.M.G.S.M., Barbosa F.A.R. \& Callisto M. 1999: Distribution and abundance of Chironomidae (Diptera, Insecta) in an impacted watershed in south-east Brazil. - Rev. Brasil. Biol. 59: 553-561.

MAtĚnA J. 1989: Seasonal dynamics of a Chironomus plumosus (L.) (Diptera, Chironomidae) population from a fish pond in southern Bohemia. - Int. Rev. Ges. Hydrobiol. 74: 599-610.

Moeller-Pillot H.K.M. 2009: Chironomidae Larvae. Biology and Ecology of the Chironomini. KNNV Publishing, Zeist, 270 pp.

Nixdorf B., Wollmann K. \& Deneke R. 1998: Ecological potentials for planctonic development and food web interactions in extremly acidic mining lakes in Lusatia. In Geller W., Klapper H. \& Salemens W. (eds): Acidic Mining Lakes. Acid Mine Drainage, Limnology and Reclamation. Springer, Berlin, pp. 147-167.

Palmén E. \& Aho L. 1966: Studies on the ecology and phenology of the Chironomidae (Dipt.) of the Northern Baltic. 2. Camptochironomus Kieff. and Chironomus Meig. - Ann. Zool. Fenn. 3: 217-244.

PARMA S. \& KREBS B.P.M. 1977: The distribution of chironomid larvae in relation to chloride concentration in a brackish water region of the Netherlands. - Hydrobiologia 52: 117-126.

Pecharová M., Hezina T., Procházka J., Přikryl I. \& Pokorný J. 2001: Restoration of spoil heaps in northwestern Bohemia using wetlands. In Vymazal J. (ed.): Transformations of Nutri- ents in Natural and Constructed Wetlands. Backhuys, Leiden, pp. 129-142.

Parsons T.R., Maita Y. \& Lalli C.M. 1984: A Manual of Chemical and Biological Methods for Seawater Analysis. Pergamon Press, Oxford, 173 pp.

PitTer P. 2009: Hydrochemistry. 4th ed. VSCHT, Prague, 579 pp. [in Czech].

Rajabipour F., Mashait N., Saresangi H., Bitaraf A., MohamMADI M. \& SAHRAgard A. 2011: Chironomus aprilinus Meigen, 1830 , production in underground brackish waters of Iran. Acad. J. Entomol. 4: 41-46.

Ramdani M., Flower R.J., Elkhiati N., Birks H.H., Kraïem M.M. \& FATHI A.A. 2001: Zooplankton (Cladocera, Ostracoda), Chironomidae and other benthic faunal remains in sediment cores from nine North African wetland lakes: the CASSARINA Project. - Aquat. Ecol. 35: 389-403.

REHFISH M.M. 1994: Man made lagoons and haw they attractiveness to waders might be increased by manipulating the biomass of an insect bentos. - J. Appl. Ecol. 31: 383-401.

SAETHER O.A. 1980: Glossary of chironomid morphology terminology (Chironomidae: Diptera). - Entomol. Scand. (Suppl.) 14: $1-51$.

STEENBERGEN H.A. 1993: Macrofauna-atlas van Noord-Holland: Verspreidingskaarten en responisies op milieufactoren van ongewervelde waterdieren. Prov. Nord-Holland, Dienst Ruimte en Groen, Haarlem, 650 pp.

StrenzKe K. 1960: Die systematische und ökologische Differenzierung der Gattung Chironomus. - Ann. Zool. Fenn. 26: $111-138$.

Ter Braak C.J.F. \& Šmilauer P. 1998: CANOCO Release 4. Reference Manual and User's Guide to Canoco for Windows: Software for Canonical Community Ordination. Microcomputer Power, Ithaca, NY, $351 \mathrm{pp}$.

Ter BraAk C.J.F. \& Šmilauer P. 2002: CANOCO Reference Manual and CanoDraw for Windows User's Guide: Software for Canonical Community Ordination, Ver. 4.5. Microcomputer Power, Ithaca, NY, $500 \mathrm{pp}$.

Thienemann A. 1954: Chironomus. Leben, Verbreitung und wirtschaftliche Bedeutung der Chironomiden. E. Schweizerbartsche, Stuttgart, $834 \mathrm{pp}$.

TOURENQ J.N. 1976: Recherches écologiques sur les chironomides (Diptera) de Camargue. I. Etude faunistique et biogéographique. - Ann. Limnol. 12: 17-74.

WebB C.J. \& Scholl A. 1985: Identification of larvae of European Chironomus Meigen (Diptera, Chironomidae) by morphological characters. - Syst. Entomol. 10: 353-372.

YadaV M. 2003: Physiology of Insect. Discovery Publishing, New Delhi, 356 pp.

ZetTLeR M.L. \& BicK A. 1996: The analysis of small and mesoscale dispersion patterns of Marenzelleria viridis (Polychaeta: Spionidae) in a coastal water area of the southern Baltic. Helgol. Meeresunt. 50: 265-286.

Received November 20, 2014; revised and accepted September 14, 2015 Published online January 28, 2016 